\begin{tabular}{|l|l|l||}
\hline \multicolumn{2}{|c|}{ PublisherInfo } \\
\hline \hline PublisherName & $:$ & BioMed Central \\
\hline \hline PublisherLocation & $:$ & London \\
\hline \hline PublisherImprintName & $:$ & BioMed Central \\
\hline \hline
\end{tabular}

\title{
Prion-driven evolution
}

\begin{tabular}{|l|l|l||}
\hline \multicolumn{2}{|c|}{ ArticleInfo } \\
\hline \hline ArticleID & $:$ & 3790 \\
\hline \hline ArticleDOI & $:$ & $10.1186 /$ gb-spotlight-20001006-01 \\
\hline \hline ArticleCitationID & $:$ & spotlight-20001006-01 \\
\hline \hline ArticleSequenceNumber & $:$ & 227 \\
\hline \hline ArticleCategory & $:$ & Research news \\
\hline \hline ArticleFirstPage & $:$ & 1 \\
\hline \hline ArticleLastPage & $:$ & 2 \\
\hline \hline & & RegistrationDate : 2000-10-06 \\
ArticleHistory & $:$ & OnlineDate \\
\hline \hline ArticleCopyright & $:$ & BioMed Central Ltd2000-10-06 \\
\hline \hline ArticleGrants & $:$ & \\
\hline \hline ArticleContext & $:$ & 130591111 \\
\hline \hline
\end{tabular}




\section{William Wells}

Email: wells@biotext.com

The yeast protein Sup35 is essential for translation termination, but its prion [PSI+] form reduces the fidelity of the termination process. Conversion of Sup35 into the prion form could therefore alter the sequence of multiple proteins at the same time, perhaps providing an engine for evolutionary change. In the 28 September Nature, True and Lindquist find that in nearly half of a long list of culture conditions tested, the presence of [PSI+] exerted a substantial effect on strain growth (Nature 2000, 407:477-483). In more than $25 \%$ of the tests the effect was positive. True and Lindquist suggest that [PSI+] can facilitate the evolution of new traits by converting previously neutral genetic variation to a non-neutral state. In an accompanying News and Views (Nature 2000, 407:457-458), Partridge and Barton do not dispute the data, but do disagree with its interpretation. They propose that the variability is a side-effect of disrupted gene expression, not an adaptation to facilitate evolution.

\section{References}

1. Support for the prion hypothesis for inheritance of a phenotypic trait in yeast.

2. Nature, [http://www.nature.com/nature/] 